\begin{tabular}{|c|c|}
\hline 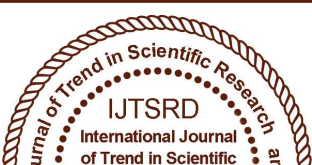 & $\begin{array}{l}\text { International Journal of Trend in Scientific } \\
\text { Research and Development (IJTSRD) }\end{array}$ \\
\hline 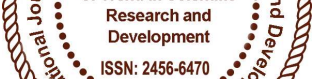 & International Open Access Journal \\
\hline 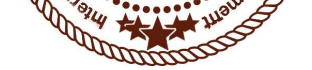 & ISSN No: 2456 - 6470 | www.ijtsrd.com | Volume - 1 | Issue - 5 \\
\hline
\end{tabular}

\title{
Correlation of Outdoor Games and Lung Function of School Going Children
}

\author{
D.Savita \\ Ph.D. Research Scholar \\ P.G. and Research Department of Home Science, \\ Bharathidasan Govt. College for Women \\ (Autonomous), Puducherry (U.T.) India
}

\author{
V. Raji Sugumar \\ Research Guide \\ P.G. and Research Department of Home Science, \\ Bharathidasan Govt. College for Women \\ (Autonomous), Puducherry (U.T.) India
}

\begin{abstract}
Outdoor games and playful workout routines can be the tools that instill not only lasting joy of exercise but also wellbeing of the children. The present research aims to investigate the relationship between outdoor games and lung function of school going children. A cross sectional school based study was carried out among 1926 school going children (10-14years) including both girls and boys from each of the 4 regions of the Union Territory of Puducherry by stratified random sampling method. Through interview schedule information regarding sociodemographic background, health status and lifestyle pattern were elicited. Nutritional status was determined using anthropometric measurements (height, weight and chest circumference) and body mass index. Peak flow meter and pulse oximeter were used to analyze the peak expiratory flow rate (PEFR), oxygen saturation and pulse rate. Data was analyzed using SPSS version 18.0. Outdoor games had a significant correlation with BMI $(p=0.010)$ and PEFR value (0.000). The mean difference in PEFR value between those engaged in outdoor games for $<1$ hour and 1 to 2 hours per day was found to be $13 \mathrm{~L} / \mathrm{min}$. The pulse rate was found to be higher among those who spent $<1$ hour. Therefore, this study concludes that outdoor games have a positive effect on the lung function of children.
\end{abstract}

Keywords: Lung function, school going children, anthropometric measurements, outdoor games

\section{INTRODUCTION}

The child population is one of the most important sections of society which being vulnerable needs very careful nurturance. Only a healthy generation of children will lead to a healthy generation of productive young people and adults. Though most non-communicable diseases (NCDs) occur in adulthood, the precursors of NCDs, as well as other health problems associated with inadequate physical activity, often begin early in childhood and adolescence (Hallal et al., 2006; Sternby et al., 1999). Physical activity during the childhood period is important because it is one of the best ways by which children can improve not only their muscle power and stamina but also health and well-being. Children increase their over-all fitness through exercise (Gavin, Dowshen and Izenberg, 2004). Although physical activity is known to have a positive effect on health and development of young children, not all children are meeting the physical activity recommendations. Physical activity has been shown to decline during adolescence globally (Biddle et al., 2004; Jago et al., 2008; Marcus et al., 2000, Swaminathan et al., 2011). There are a myriad of health benefits for children who spend time playing outdoors. The amount of physical activity young children participate in varies widely across studies (Okely and Jones, 2011). Self-reported data from 39 countries indicate that only $23 \%$ and $19 \%$ of 11 and 13 year olds achieve the recommended 
International Journal of Trend in Scientific Research and Development (IJTSRD) ISSN: 2456-6470

60 min per day of moderate-to-vigorous physical activity (Hallal et al, 2014). According to Hinkley (2011) in the last 10 years or so, it has become evident that many young children do not participate in sufficient physical activity for health and hence high levels of physical inactivity and sedentary behavior are becoming a global concern. The advent of entertainment and communication devices such as lap top, television, mobile, video games, iPod, iPad, television, and internet has led to the decrease in the frequency and duration of outdoor recreation activities by children due to the emergence of newer leisure opportunities (Kansal \& Ohri, 2014). Therefore, the purpose of the current study was to evaluate the relationship between outdoor games and lung function among school going children.

\section{Methodology}

A cross sectional school based study was conducted during June 2015 to February 2017 in each of the 4 regions of the Union Territory of Puducherry namely Puducherry, Karaikal, Mahe and Yanam after obtaining permission from the Director of Education.

The study population consisted of 1926 school going children (10-14 years) both boys and girls selected by stratified random sampling method from rural and urban areas.

Data pertaining to socio-demographic, health status and lifestyle pattern was collected by interview schedule.

Anthropometric measurements such as height weight and chest circumference were taken and body mass index was calculated using the formula Weight $(\mathrm{Kg}) /$ Height $\left(\mathrm{m}^{2}\right)$. Peak expiratory flow rate, oxygen saturation $\left(\mathrm{SPO}_{2}\right)$ and pulse rate were measured to analyze their lung function. The data is expressed in numbers and percentage. ANOVA was used to compare the BMI and lung function with average hours spent in outdoor games and $\mathrm{p}$ value was also determined.

\section{Results and Discussions}

The results of the study are presented and discussed as follows:

It is evident from Table 1 that girls (51.03\%) outnumbered boys $(48.96 \%)$.
Table 1. Distribution of the sample based on sex

\begin{tabular}{|c|c|c|}
\hline Sex & Number & \% \\
\hline Girls & 983 & 51.03 \\
\hline Boys & 943 & 48.96 \\
\hline Total & $\mathbf{1 9 2 6}$ & $\mathbf{1 0 0}$ \\
\hline
\end{tabular}

Table 2. shows that the study population belonging to urban area was higher $(53.11 \%)$ than rural area (46.88) with a difference of $6.23 \%$.

Table 2. Distribution of the sample based on location

\begin{tabular}{|c|c|c|}
\hline Location & Number & \% \\
\hline Urban & 1023 & 53.11 \\
\hline Rural & 903 & 46.88 \\
\hline
\end{tabular}

Table 3. Distribution of the sample based on average hours engaged in outdoor games

\begin{tabular}{|c|c|c|}
\hline $\begin{array}{c}\text { Average hours } \\
\text { engaged in } \\
\text { outdoor games }\end{array}$ & No. & \% \\
\hline$<\mathbf{1}$ hr & 429 & 22.27 \\
\hline 1 to $\mathbf{2}$ hrs & 1282 & 66.56 \\
\hline 3 to 4 hrs & 215 & 11.16 \\
\hline
\end{tabular}

The distribution of the sample based on average hours engaged in outdoor games (Table 3) points out that the proportion of children engaging in 1 to 2 hours of outdoor games was higher $(66.56 \%)$ compared to $<1$ hour $(22.27 \%)$ and 3 to 4 hours per day $(11.16 \%)$.

Table 4 depicts the distribution of sample based on region, location and sex with respect to average time spent in outdoor games. It is evident from the table that the children in all the 4 regions except Yanam were engaged on an average of 1 to 2 hours in outdoor games followed by $<1$ hour. More number of children (25) in Yanam participated in outdoor games for 3 to 4 hours when compared to other regions.

In Puducherry the number of girls from both rural and urban areas engaged in 1 to 2 hours and $<1$ hour of outdoor games was higher than boys. Boys outnumbered the girls in the time spent in outdoor games for 3 to 4 hours.

The participation of boys in outdoor games (in all three categories) from both rural and urban areas of Karaikal were found to be higher than girls except in urban area ( $<1$ hour). 
International Journal of Trend in Scientific Research and Development (IJTSRD) ISSN: 2456-6470

None of the children in the rural area of Mahe showed participation in outdoor games for $<1$ hour. Majority of the girls $(80.3 \%)$ and boys $(66.7 \%)$ in urban areas were seen to be engaged in $<1$ hour and 3 to 4 hours of outdoor games respectively. In rural areas, girls $(6.1 \%)$ engaged in 1 to 2 hours of outdoor games outnumbered boys $(3.8 \%)$ but in 3 to 4 hours of outdoor games they were both equal and least in number (only 1).
Higher percentage of girls (52.5\%) and boys (34.2\%) in the urban areas of Yanam spent on an average 1 to 2 hours in outdoor games. The average time engaged in 3 to 4 hours of outdoor games by boys was higher than girls both in rural and urban areas with a difference of $32 \%$ and $28 \%$ respectively. A clear gender difference was found in this study. Physical activity tracked better in boys than in girls and this study is in tune with other studies by Tammelin et al. (2003) and Pate et al (1999).

Table 4. Distribution of sample based on region, location and sex

\begin{tabular}{|c|c|c|c|c|c|c|c|c|c|c|c|c|c|c|c|c|c|c|c|c|}
\hline \multirow{3}{*}{$\begin{array}{l}\text { Avera } \\
\text { ge } \\
\text { time } \\
\text { spent } \\
\text { in } \\
\text { outdo } \\
\text { or } \\
\text { games } \\
\text { per } \\
\text { day }\end{array}$} & \multicolumn{5}{|c|}{ Puducherry ( $\mathrm{N}=1187$ ) } & \multicolumn{5}{|c|}{ Karaikal ( $\mathrm{N}=435)$} & \multicolumn{5}{|c|}{ Mahe $(\mathrm{N}=\mathbf{2 0 9})$} & \multicolumn{5}{|c|}{ Yanam $(\mathrm{N}=203)$} \\
\hline & \multicolumn{2}{|c|}{ Rural } & \multicolumn{2}{|c|}{ Urban } & \multirow{2}{*}{$\stackrel{\frac{\pi}{0}}{\theta}$} & \multicolumn{2}{|c|}{ Rural } & \multicolumn{2}{|c|}{ Urban } & \multirow{2}{*}{$\stackrel{\sqrt[\pi]{0}}{\ominus}$} & \multicolumn{2}{|c|}{ Rural } & \multicolumn{2}{|c|}{ Urban } & \multirow{2}{*}{ है } & \multicolumn{2}{|c|}{ Rural } & \multicolumn{2}{|c|}{ Urban } & \multirow{2}{*}{ 胥 } \\
\hline & $\mathbf{G}$ & B & $\mathbf{G}$ & B & & $\mathbf{G}$ & B & $\mathbf{G}$ & B & & $\mathbf{G}$ & B & $\mathbf{G}$ & B & & $\mathbf{G}$ & B & $\mathbf{G}$ & B & \\
\hline $\begin{array}{l}<1 \\
\text { hour }\end{array}$ & 78 & 36 & 87 & 30 & $\begin{array}{c}23 \\
1\end{array}$ & 36 & 49 & 39 & 28 & $\begin{array}{c}15 \\
2\end{array}$ & 0 & 0 & 53 & 13 & 66 & 1 & 2 & 8 & 9 & 20 \\
\hline$\%$ & $\begin{array}{c}33 . \\
8\end{array}$ & $\begin{array}{c}15 . \\
6\end{array}$ & $\begin{array}{c}37 . \\
7\end{array}$ & 13 & $\begin{array}{c}10 \\
0\end{array}$ & $\begin{array}{c}23 . \\
7\end{array}$ & $\begin{array}{c}32 . \\
2\end{array}$ & $\begin{array}{c}23 . \\
7\end{array}$ & $\begin{array}{c}18 . \\
4\end{array}$ & $\begin{array}{c}10 \\
0\end{array}$ & 0 & 0 & $\begin{array}{c}80 . \\
3\end{array}$ & $\begin{array}{c}19 . \\
7\end{array}$ & $\begin{array}{c}10 \\
0\end{array}$ & 5 & 10 & 40 & 45 & $\begin{array}{c}10 \\
0\end{array}$ \\
\hline $\begin{array}{l}1 \text { to } 2 \\
\text { hours }\end{array}$ & $\begin{array}{c}22 \\
6\end{array}$ & $\begin{array}{c}21 \\
7\end{array}$ & $\begin{array}{c}22 \\
8\end{array}$ & $\begin{array}{c}15 \\
6\end{array}$ & $\begin{array}{c}82 \\
7\end{array}$ & 35 & 91 & 31 & 65 & $\begin{array}{c}22 \\
2\end{array}$ & 8 & 5 & 47 & 71 & $\begin{array}{c}13 \\
1\end{array}$ & 3 & 18 & 83 & 54 & $\begin{array}{c}15 \\
8\end{array}$ \\
\hline$\%$ & $\begin{array}{c}27 . \\
3\end{array}$ & $\begin{array}{c}26 . \\
2\end{array}$ & $\begin{array}{c}27 . \\
6\end{array}$ & $\begin{array}{c}18 . \\
9\end{array}$ & $\begin{array}{c}10 \\
0\end{array}$ & $\begin{array}{c}15 . \\
8\end{array}$ & 41 & 14 & $\begin{array}{c}29 . \\
3\end{array}$ & $\begin{array}{c}10 \\
0\end{array}$ & $\begin{array}{c}6 . \\
1\end{array}$ & $\begin{array}{l}3 . \\
8\end{array}$ & $\begin{array}{c}35 . \\
9\end{array}$ & $\begin{array}{c}54 . \\
2\end{array}$ & $\begin{array}{c}10 \\
0\end{array}$ & $\begin{array}{l}1 . \\
9\end{array}$ & $\begin{array}{c}11 . \\
4\end{array}$ & $\begin{array}{c}52 . \\
5\end{array}$ & $\begin{array}{c}34 . \\
2\end{array}$ & $\begin{array}{c}10 \\
0\end{array}$ \\
\hline $\begin{array}{l}3 \text { to } 4 \\
\text { hours }\end{array}$ & 28 & 44 & 18 & 39 & $\begin{array}{c}12 \\
9\end{array}$ & 6 & 30 & 10 & 15 & 61 & $\begin{array}{l}1 . \\
0\end{array}$ & $\begin{array}{l}1 . \\
0\end{array}$ & 2.0 & 8.0 & 12 & $\begin{array}{c}2 . \\
0\end{array}$ & $\begin{array}{c}10 . \\
0\end{array}$ & 3.0 & $\begin{array}{c}10 . \\
0\end{array}$ & 25 \\
\hline$\%$ & $\begin{array}{c}21 . \\
7\end{array}$ & $\begin{array}{c}34 . \\
1\end{array}$ & 14 & $\begin{array}{c}30 . \\
2\end{array}$ & $\begin{array}{c}10 \\
0\end{array}$ & 9.8 & $\begin{array}{c}49 . \\
2\end{array}$ & $\begin{array}{c}16 . \\
4\end{array}$ & $\begin{array}{c}24 . \\
6\end{array}$ & $\begin{array}{c}10 \\
0\end{array}$ & $\begin{array}{l}8 . \\
3\end{array}$ & $\begin{array}{l}8 . \\
3\end{array}$ & $\begin{array}{c}16 . \\
7\end{array}$ & $\begin{array}{c}66 . \\
7\end{array}$ & $\begin{array}{c}10 \\
0\end{array}$ & 8 & 40 & 12 & 40 & $\begin{array}{c}10 \\
0\end{array}$ \\
\hline
\end{tabular}

Table 5. Hours spent in outdoor games Vs. Nutritional status and lung function test

\begin{tabular}{|c|c|c|c|c|c|c|c|c|c|c|c|c|c|}
\hline \multirow{2}{*}{$\begin{array}{c}\text { Average } \\
\text { hours } \\
\text { engaged } \\
\text { in outdoor } \\
\text { games }\end{array}$} & \multirow[t]{2}{*}{ No. } & \multicolumn{3}{|c|}{ Nutritional status } & \multicolumn{9}{|c|}{ Lung function test } \\
\hline & & BMI & $\begin{array}{l}\text { F- } \\
\text { stat }\end{array}$ & $\begin{array}{c}\text { p- } \\
\text { value }\end{array}$ & $\begin{array}{c}\text { PEFR } \\
\text { (L/min } \\
\quad)\end{array}$ & F-stat & $\begin{array}{c}\text { p- } \\
\text { value }\end{array}$ & $\begin{array}{c}\mathrm{SPO}_{2} \\
(\%)\end{array}$ & $\begin{array}{c}\text { F- } \\
\text { stat }\end{array}$ & $\begin{array}{c}\text { p- } \\
\text { value }\end{array}$ & $\begin{array}{l}\text { Pulse } \\
\text { Rate } \\
\text { (Beat } \\
\text { s/min } \\
\text { ) }\end{array}$ & $\begin{array}{c}\text { F- } \\
\text { stat }\end{array}$ & $\begin{array}{c}\text { p- } \\
\text { value }\end{array}$ \\
\hline$<1 \mathrm{hr}$ & 429 & $\begin{array}{c}17.80 \\
5 \\
\end{array}$ & \multirow[t]{3}{*}{$\begin{array}{c}6.61 \\
7\end{array}$} & \multirow[t]{3}{*}{$\begin{array}{c}0.010 \\
*\end{array}$} & 270.12 & \multirow[t]{3}{*}{$\begin{array}{c}13.87 \\
2\end{array}$} & \multirow[t]{3}{*}{$\begin{array}{c}0.000 \\
*\end{array}$} & 98.13 & \multirow[t]{3}{*}{$\begin{array}{c}0.07 \\
3\end{array}$} & \multirow[t]{3}{*}{$\underset{\text { NS }}{0.787}$} & 93.18 & \multirow[t]{3}{*}{$\begin{array}{c}0.72 \\
4\end{array}$} & \multirow[t]{3}{*}{$\underset{\mathrm{NS}}{0.505}$} \\
\hline 1 to $2 \mathrm{hrs}$ & 215 & $\begin{array}{c}17.29 \\
5\end{array}$ & & & 283.00 & & & 98.23 & & & 92.88 & & \\
\hline 3 to 4 hrs & $\begin{array}{c}128 \\
2\end{array}$ & $\begin{array}{c}17.46 \\
6\end{array}$ & & & 287.34 & & & 98.26 & & & 91.67 & & \\
\hline
\end{tabular}


International Journal of Trend in Scientific Research and Development (IJTSRD) ISSN: 2456-6470

The hours spent in outdoor games had a positive effect on lung function of the school going children (Table 5). The mean PEFR $(287.34 \mathrm{~L} / \mathrm{min})$ and $\mathrm{SPO}_{2}(98.26 \%)$ values of the school going children who were engaged in outdoor games for 3 to 4 hours were found to be higher. Lower level of pulse rate (91.67 beats/min) was obtained in the children who spent 1 to 2 hours or less. This shows that the participation in outdoor games is directly proportional to the PEFR and highly significant. The BMI representing the nutritional status of the children reveals that all the samples were underweight having a BMI of $<18.5$ but there was a significant difference in the BMI among children which varied with the hours spent in outdoor games per day.

Table 6. Hours spent by the sample in outdoor games Vs. Nutritional status and lung function test

\begin{tabular}{|c|c|c|c|c|c|c|c|c|c|c|c|c|c|c|c|c|c|c|}
\hline \multirow{2}{*}{$\begin{array}{l}\text { Out } \\
\text { door } \\
\text { gam } \\
\text { es }\end{array}$} & \multirow[t]{2}{*}{ Sex } & \multirow{2}{*}{$\begin{array}{c}\text { Lo } \\
\text { ca } \\
\text { tio } \\
\text { n }\end{array}$} & \multicolumn{4}{|c|}{ Puducherry } & \multicolumn{4}{|c|}{ Karaikal } & \multicolumn{4}{|c|}{ Mahe } & \multicolumn{4}{|c|}{ Yanam } \\
\hline & & & $\begin{array}{c}\text { BM } \\
\text { I }\end{array}$ & $\begin{array}{l}\text { SP } \\
\mathbf{O}_{2} \\
(\%)\end{array}$ & $\begin{array}{c}\text { Puls } \\
\text { e } \\
\text { (Bea } \\
\text { ts } / \mathbf{m i} \\
\text { n) }\end{array}$ & $\begin{array}{c}\text { PEF } \\
\mathbf{R} \\
(\mathbf{L} / \mathbf{m} \\
\text { in) }\end{array}$ & $\begin{array}{c}\text { B } \\
\text { MI }\end{array}$ & $\begin{array}{l}\text { SP } \\
\mathbf{O}_{2} \\
(\%)\end{array}$ & $\begin{array}{c}\text { Pul } \\
\text { se } \\
\text { (Be } \\
\text { ats/ } \\
\text { min } \\
\text { ) }\end{array}$ & $\begin{array}{c}\text { PEF } \\
R \\
(\mathbf{L} / \mathbf{m} \\
\text { in) }\end{array}$ & $\begin{array}{c}\text { BM } \\
\text { I }\end{array}$ & $\begin{array}{l}\mathrm{SP} \\
\mathrm{O}_{2} \\
(\%)\end{array}$ & $\begin{array}{c}\text { Pul } \\
\text { se } \\
\text { (Be } \\
\text { ats/ } \\
\text { min } \\
\text { ) }\end{array}$ & $\begin{array}{c}\text { PEF } \\
R \\
(\mathrm{~L} / \mathrm{m} \\
\text { in })\end{array}$ & $\begin{array}{c}\text { B } \\
\text { MI }\end{array}$ & $\begin{array}{l}\mathrm{SP} \\
\mathrm{O}_{2} \\
(\%)\end{array}$ & $\begin{array}{c}\text { Pul } \\
\text { se } \\
(\mathrm{Be} \\
\text { ats/ } \\
\text { min } \\
\text { ) }\end{array}$ & $\begin{array}{c}\text { PEF } \\
\text { R } \\
(\mathbf{L} / \mathbf{m i} \\
\mathbf{n})\end{array}$ \\
\hline \multirow[t]{4}{*}{$\begin{array}{l}<1 \\
\text { hour }\end{array}$} & \multirow[t]{2}{*}{ Girls } & $\begin{array}{l}\text { Rur } \\
\text { al }\end{array}$ & 17.8 & 98.7 & 93.2 & $\begin{array}{l}292 . \\
3\end{array}$ & $\begin{array}{l}20 . \\
0\end{array}$ & 97.5 & 95.6 & $\begin{array}{l}184 . \\
1\end{array}$ & - & - & - & - & $\begin{array}{l}23 . \\
1\end{array}$ & 99.0 & 78.0 & 300.0 \\
\hline & & $\begin{array}{l}\text { Ur } \\
\text { ban }\end{array}$ & 17.5 & 98.3 & 95.7 & $\begin{array}{l}267 . \\
8\end{array}$ & $\begin{array}{l}18 . \\
1\end{array}$ & 98.1 & 86.5 & $\begin{array}{l}194 . \\
5\end{array}$ & 18.5 & 98.0 & 97.1 & $\begin{array}{l}309 . \\
4\end{array}$ & $\begin{array}{l}18 . \\
6\end{array}$ & 97.6 & 94.6 & 283.8 \\
\hline & \multirow[t]{2}{*}{ Boys } & $\begin{array}{l}\text { Rur } \\
\text { al }\end{array}$ & 15.4 & 98.2 & 89.8 & $\begin{array}{l}264 . \\
2 \\
\end{array}$ & $\begin{array}{l}18 . \\
5 \\
\end{array}$ & 98.3 & 89.2 & $\begin{array}{l}239 \\
8 \\
\end{array}$ & - & - & - & - & $\begin{array}{l}16 . \\
3 \\
\end{array}$ & 98.0 & 94.0 & 380.0 \\
\hline & & $\begin{array}{l}\text { Ur } \\
\text { ban }\end{array}$ & 16.4 & 98.6 & 90.9 & $\begin{array}{l}275 . \\
3 \\
\end{array}$ & $\begin{array}{l}17 . \\
7\end{array}$ & 98.6 & 88.6 & $\begin{array}{l}237 . \\
8 \\
\end{array}$ & 19.5 & 97.1 & 96.2 & $\begin{array}{l}392 . \\
3\end{array}$ & $\begin{array}{l}17 . \\
9\end{array}$ & 98.8 & 99.3 & 307.8 \\
\hline \multirow{4}{*}{$\begin{array}{l}1 \text { to } \\
2 \\
\text { hour } \\
\text { s }\end{array}$} & \multirow[t]{2}{*}{ Girls } & $\begin{array}{l}\text { Rur } \\
\text { al }\end{array}$ & 17.7 & 98.4 & 93.4 & $\begin{array}{l}295 . \\
7 \\
\end{array}$ & $\begin{array}{l}19 . \\
6\end{array}$ & 98.0 & 89.4 & $\begin{array}{l}194 . \\
5 \\
\end{array}$ & 19.0 & 98.3 & $\begin{array}{l}101 . \\
6\end{array}$ & $\begin{array}{l}340 . \\
0\end{array}$ & $\begin{array}{l}17 . \\
8\end{array}$ & 97.7 & 89.0 & 313.3 \\
\hline & & $\begin{array}{l}\text { Ur } \\
\text { ban }\end{array}$ & 17.0 & 98.4 & 96.1 & $\begin{array}{l}260 . \\
7 \\
\end{array}$ & $\begin{array}{l}17 . \\
3\end{array}$ & 97.7 & 96.1 & $\begin{array}{l}195 . \\
6\end{array}$ & 18.4 & 98.4 & 96.9 & $\begin{array}{l}314 . \\
0\end{array}$ & $\begin{array}{l}17 . \\
5\end{array}$ & 97.3 & 89.9 & 291.9 \\
\hline & \multirow[t]{2}{*}{ Boys } & $\begin{array}{l}\text { Rur } \\
\text { al }\end{array}$ & 15.9 & 98.3 & 92.4 & $\begin{array}{l}283 . \\
2 \\
\end{array}$ & $\begin{array}{l}18 . \\
0\end{array}$ & 98.0 & 87.4 & $\begin{array}{l}263 . \\
1 \\
\end{array}$ & 17.6 & 98.6 & 81.6 & $\begin{array}{l}472 . \\
0\end{array}$ & $\begin{array}{l}16 . \\
6 \\
\end{array}$ & 98.4 & 90.3 & 315.6 \\
\hline & & $\begin{array}{l}\text { Ur } \\
\text { ban }\end{array}$ & 17.1 & 98.2 & 93.0 & $\begin{array}{l}293 . \\
2\end{array}$ & $\begin{array}{l}17 . \\
7\end{array}$ & 97.8 & 86.1 & $\begin{array}{l}262 . \\
9\end{array}$ & 18.5 & 98.2 & 94.6 & $\begin{array}{l}377 . \\
7\end{array}$ & $\begin{array}{l}17 . \\
5\end{array}$ & 98.7 & 92.1 & 313.9 \\
\hline \multirow{4}{*}{$\begin{array}{l}3 \text { to } \\
4 \\
\text { hour } \\
\text { s }\end{array}$} & \multirow[t]{2}{*}{ Girls } & $\begin{array}{l}\text { Rur } \\
\text { al }\end{array}$ & 17.0 & 98.4 & 93.1 & $\begin{array}{l}295 . \\
0 \\
\end{array}$ & $\begin{array}{l}18 . \\
8\end{array}$ & 97.7 & 88.5 & $\begin{array}{l}193 . \\
5\end{array}$ & 16.8 & 98.0 & $\begin{array}{l}109 . \\
0\end{array}$ & $\begin{array}{l}350 . \\
0\end{array}$ & $\begin{array}{l}17 . \\
3\end{array}$ & 98.5 & 95.0 & 452.5 \\
\hline & & $\begin{array}{l}\text { Ur } \\
\text { ban }\end{array}$ & 17.9 & 98.2 & 92.9 & $\begin{array}{l}240 . \\
0 \\
\end{array}$ & $\begin{array}{l}18 . \\
8 \\
\end{array}$ & 98.1 & 99.0 & $\begin{array}{l}191 . \\
4\end{array}$ & 13.8 & 97.5 & 96.5 & $\begin{array}{l}355 . \\
0\end{array}$ & $\begin{array}{l}17 . \\
1 \\
\end{array}$ & 99.0 & $\begin{array}{l}101 . \\
0\end{array}$ & 273.3 \\
\hline & \multirow[t]{2}{*}{ Boys } & $\begin{array}{l}\text { Rur } \\
\text { al }\end{array}$ & 16.5 & 98.2 & 92.3 & $\begin{array}{l}289 \\
8 \\
\end{array}$ & $\begin{array}{l}18 . \\
4\end{array}$ & 98.0 & 85.5 & $\begin{array}{l}259 . \\
6\end{array}$ & 16.3 & 99.0 & 99.0 & $\begin{array}{l}450 . \\
0\end{array}$ & $\begin{array}{l}17 . \\
4\end{array}$ & 98.6 & 90.9 & 331.0 \\
\hline & & $\begin{array}{l}\text { Ur } \\
\text { ban }\end{array}$ & 17.3 & 98.0 & 93.2 & $\begin{array}{l}295 . \\
4\end{array}$ & $\begin{array}{l}20 . \\
7\end{array}$ & 98.6 & 93.4 & $\begin{array}{l}224 . \\
4\end{array}$ & 18.4 & 97.8 & 88.0 & $\begin{array}{l}351 . \\
3\end{array}$ & $\begin{array}{l}16 . \\
0\end{array}$ & 97.6 & 85.6 & 311.0 \\
\hline
\end{tabular}

From Table 6 it can be inferred that the BMI of girls in rural areas is higher than urban areas in all the 4 regions except in Puducherry and Karaikal (3 to 4 hours). The urban boys of Puducherry, Mahe and Yanam had a higher BMI. In Karaikal the BMI was found to be higher among the rural boys who were engaged in $<1$ hour and 1 to 2 hours of outdoor games but lower among those in 3 to 4 hours category. Among girls it was found that majority of the children from the rural areas of all the 4 regions had better BMI when compared to their urban counterparts. The mean BMI of girls in Puducherry, Karaikal, Mahe and Yanam were 17.4, 18.7, 17.3 and 18.5 respectively thereby indicating that the girls of Puducherry and Mahe are underweight (BMI <18.5). A mean BMI of
16.4, 18.5, 18.06 and 16.95 were observed among the boys of Puducherry, Karaikal, Mahe and Yanam. Except for the boys in Karaikal all the others were underweight. When compared to boys (17.4) the mean BMI of girls (17.97) was found to be higher. The mean $\mathrm{SPO}_{2}$ values of rural girls in Puducherry, Karaikal, Mahe and Yanam were 98.5, 97.73, 98.15 and 98.4 respectively and that of urban girls were 98.3, 97.96, 97.96 and 97.6 respectively. Mean pulse rate of 98.2, 98.0, 98.8 and 98.3 in rural boys and 98.2, 98.3, 97.7 and 98.3 in urban boys were observed in Puducherry, Karaikal, Mahe and Yanam respectively. 
International Journal of Trend in Scientific Research and Development (IJTSRD) ISSN: 2456-6470

The mean pulse rate of rural girls in Puducherry, Karaikal and Yanam (93.23, 91.1, and 87.3) were lower than the urban girls $(94.9,93.8$, and 95.16). In Mahe rural girls showed higher pulse rate of 105.3 compared to urban girls (96.8). Boys belonging to the rural areas of Puducherry, Karaikal, Mahe and Yanam (91.5, 87.3, 90.3 and 91.7) had lower pulse rate than the urban areas in each of the 4 regions respectively $(92.3,92.93,92.9$ and 92.3$)$.

Among the 4 regions the mean PEFR values of rural girls in Yanam were found to be the highest (355.2) followed by Mahe (345), Puducherry (294.3) and Karaikal (190.7). Mahe (326.1) reported highest PEFR among urban girls followed by Yanam (283), Puducherry (256.1) and Karaikal (193.9). Boys belonging to both rural and urban areas of Mahe had the highest PEFR than Yanam, Puducherry and Karaikal. Majority of the children in rural areas were found to have higher PEFR than urban areas. Among the 4 regions, Karaikal had the lowest PEFR value. The PEFR of rural girls (190.7) were lower than urban girls (193.9).

\section{Conclusion}

Outdoor games greatly influence the health of the children by increasing the lung capacity. Girls are mostly found to restrict their involvement in outdoor games during their recreation hours. They engage in outdoor games only during the physical education period within the school hours. Now a days, both boys and girls prefer indoor games to outdoor games and spend more time with technological gadgets such as internet, mobile games, computer games etc. It is the need of the hour to highlight and stress the importance of outdoor games with health and wellbeing. Hence, the children who are the future generation should be encouraged to regularly participate in outdoor games irrespective of sexes.

\section{References:}

Biddle, S., Gorely, T., \& Stensel, D. (2004). Healthenhancing physical activity and sedentary behaviour in children and adolescents. J. Sports Sci, 22, 679701 .

Gavin ML (Medical Editor, KidsHealth.org), Dowshen SA (Chief Medical Editor, KidsHealth.org), and Izenberg $\mathrm{N}$ (Editor-in-Chief and Founder, KidsHealth.org). (2004). Fit KIDS, 1st edition, DK Publishing, Inc., New York, NY.

Hallal, P.C., Wells, J.C., Reichert, F.F., Anselmi, L., \& Victora, C.G. (2006). Early determinants of physical activity in adolescence: prospective birth cohort study. BMJ, 332, 1002-7.

Jago, R., Wedderkopp, N., Kristensen, P. L., Møller, N. C., Andersen, L. B., Cooper, A. R., \& Froberg, K. (2008). Six-year change in youth physical activity and effect on fasting insulin and HOMA-IR. American Journal of Preventive Medicine, 35(6), 554-560.

Kansal, O. P., \& Ohri, P. (2014). Adolescents: A key pivotal in India's health strategy. Indian Journal of Youth and Adolescent Health, 1, 48-55.

Marcus, B. H., Forsyth, L. H., Stone, E. J., Dubbert, P. M., McKenzie, T. L., Dunn, A. L., \& Blair, S. N. (2000). Physical activity behavior change: Issues in adoption and maintenance. Health Psychology, 19(Suppl.), 32-41.

Pate R, Trost SG, Dowda M, et al. (1999). Tracking of physical activity, physical inactivity, and healthrelated physical fitness in rural youth, Pediatr Exerc Sci , 11:364-76.

Sternby, N.H., Fernandez-Britto, J.E., \& Nordet, P. (1999). Pathobiological determinants of atherosclerosis in youth (PBDAY Study), 1986-96. Bull World Health Organ, 77, 250-7.

Swaminathan, S., Selvam, S., Thomas, T., Kurpad, A.V., \& Vaz, M. (2011). Longitudinal trends in physical activity patterns in selected urban south Indian school children. Indian J Med Res, 134, 174180.

Tammelin T, Näyhä S, Hills AP, Järvelin M-J. (2003). Adolescent participation in sports and adult physical activity, Am J Prev Med, 24:22-8.

Trina Hinkley, BA, Jo Salmon. (2011). Centre for Physical Activity and Nutrition Research (CPAN), Deakin University, Australia, Correlates of Physical Activity in Early Childhood, January. 